\title{
Lycophytes of the Chapada das Mesas National Park, Cerrado, Maranhão, Brazil
}

\author{
Francilene Cardoso Almeida ${ }^{1}$, Marcio Roberto Pietrobom ${ }^{2}$ \& Rozijane Santos Fernandes ${ }^{1 *}$ (10 \\ ${ }^{1}$ Universidade Federal do Maranhão, Centro de Ciências Agrárias e Ambientais, Laboratório de Sistemática \\ Vegetal, Chapadinha, MA, Brasil. \\ ${ }^{2}$ Universidade Federal do Pará, Campus Universitário de Bragança, Instituto de Estudos Costeiros, \\ Laboratório de Botânica, Bragança, PA, Brasil.
}

*Corresponding author: Rozijane Santos Fernandes, e-mail: rozijanef@hotmail.com.

ALMEIDA, F.C., PIETROBOM, M.R., FERNANDES, R.S. Lycophytes of the Chapada das Mesas National Park, Cerrado, Maranhão, Brazil. Biota Neotropica 20(3): e20200964. https://doi.org/10.1590/1676-0611BN-2020-0964.

\begin{abstract}
Despite an increase in studies involving lycophytes and ferns in recent years, Maranhão is still one of the northeastern states with a poorly known flora, mainly due to low sampling. For Chapada das Mesas National Park, a protected conservation unit in the Cerrado maranhense with phytophysiognomies that favor floristic diversity, there are no floristic studies about lycophytes. This study aimed to conduct the floristic inventory and taxonomic study of lycophytes in Chapada das Mesas National Park. Three collection expeditions, of three days each, were made between March 2017 and June 2018. Three families of lycophytes represented by three genera and six species were identified in the study area. The most diverse family was Selaginellaceae with four species: Selaginella conduplicata, S. erythropus (Mart.) Spring, S. radiata (Aubl.) Baker and S. simplex Baker. The other two families, Isoëtaceae and Lycopodiaceae, had one species each, Isoëtes sp. and Palhinhaea cernua (L.) Franco $\&$ Vasc. This study also reports two new record for the Brazilian Cerrado phytogeographic domain, S. conduplicate and S. radiata, of which the first is a new record for Maranhão State. Most specimens were found in riparian forest on rocky outcrops.
\end{abstract}

Keywords: Riparian forest; Selaginella; Taxonomy; Waterfall.

\section{Licófitas do Parque Nacional Chapada das Mesas, Cerrado Maranhense, Brasil}

Resumo: Embora as pesquisas envolvendo o estudo de licófitas e samambaias tenham crescido nos últimos anos, o Maranhão ainda é um dos Estados do Nordeste com sua flora menos conhecida em virtude, principalmente, da baixa amostragem. O Parque Nacional (PARNA) Chapada das Mesas, apesar de tratar-se de uma unidade de conservação protegida no Cerrado maranhense e abrigar fitofisionomias que são propícias à diversidade florística, ainda não possui estudos sobre a diversidade florística de licófitas. Este estudo teve como objetivo geral fazer um inventário e estudo florístico e taxonômico de licófitas para o PARNA Chapada das Mesas. Foram realizadas três expedições para coletas de material entre março 2017 e junho 2018 com duração de três dias cada. Na área de estudo foram identificadas as três famílias de licófitas representadas por três gêneros e seis espécies. A família com maior diversidade foi Selaginellaceae com quatro espécies Selaginella conduplicata, S. erythropus, S. radiata e $S$. simplex. As outras duas, Isoëtaceae e Lycopodiaceae com uma espécie cada, Isoëtes sp., e Palhinhaea cernua. Nesse estudo também são relatados dois novos registros para o domínio fitogeográfico do Cerrado, S. conduplicata e $S$. radiata, sendo a primeira um novo registro para o Estado do Maranhão. A maioria dos espécimes foi encontrada em ambientes de matas ciliares crescendo sobre afloramento rochoso.

Palavras-chave: Mata ciliar; Selaginella; Taxonomia; Cachoeira. 


\section{Introduction}

The class Lycopodiopsida, also known as lycophytes, is a monophyletic group characterized by its main leaves that are microphylls, sporangia with transversal dehiscence in the adaxial axil of the sporophyll and, in most cases, strobili forming at the branch apex (Tryon \& Tryon 1982, Banks 2009, PPG I 2016). Among vascular plants, it is considered the most basal group (Pryer et al. 2001), with the first fossil records dating to the Paleozoic era, approximately 350-410 million years ago (Kenrick \& Crane 1997).

Lycophytes are herbaceous and can be terrestrial, epiphytic, rupicolous or aquatic (Prado \& Sylvestre 2010). They are widely distributed in many ecosystems of tropical, subtropical, temperate and boreal regions, which demonstrates their great adaptive success (Moran \& Smith 2001). According to Kenrick \& Crane (1997), the extant representatives of lycophytes belong to three families, Lycopodiaceae, Isoëtaceae and Selaginellaceae, of which the first is homosporous and the last two are heterosporous.

Lycopodiaceae species are distributed on practically all continents, especially in the neotropical region (Øllgaard 1995A). According to the classification by Øllgaard (2012), the family is divided into 16 genera and represented by terrestrial, epiphytic and rupicolous plants. These taxa are highly diverse in South America, exhibiting a variety of life forms, and are found in various habitats (Arana \& Øllgaard 2012, Arana et al. 2017).

The family Isoëtaceae is monogeneric (Isoëtes), is distributed worldwide and comprises approximately 250 species and comprises plants that are usually submersed or emergent, including some that are seasonal with active growth during spring (Jermy 1990, Moran 2012, Troia et al. 2016). Due to their morphological simplicity (Taylor \& Hickey 1992), reproductive structures, such as megaspore and microspore ornamentation (Pfeiffer 1922, Hickey 1986, Musselman 2002), as well as anatomical and leaf morphology diagnostic characters, are important in the classification of the species (Rolleri \& Prada 2007).

The family Selaginellaceae is also represented by one genus, Selaginella, which is cosmopolitan and widely adapted, mainly in the tropics (Moran 2012, Tryon \& Stolze 1994). The genus is characterized by high intraspecific variability, as well as reduced interspecific variation (Schulz et al. 2013).

Lycophytes comprise approximately 1,338 species (PPG I 2016) and represent only $1 \%$ of vascular plants (Moran 2008). In Brazil, there are 186 lycophyte species, of which 49 have been recorded in the Northeast Region, a relatively low number compared to the other regions of the country, except the Central-West region where there are only 38 species. The others Brazilian regions are better sampled, with 83 in the North, 95 in the Southeast, and 64 in the South (Flora do Brasil 2020, under construction).

Although it is one of the largest states in the Northeast Region, Maranhão is still undersampled. Local floristic studies about seedless vascular plants contain few species and have recorded only eleven species of lycophytes (e.g., Bastos \& Cutrim 1999, Fernandes et al. 2007, Fernandes et al. 2010, Conceição \& Rodrigues 2010, Silva et al. 2017, Santos-Silva et al. 2018, Flora do Brasil 2020, under construction). Maranhão State is situated in an ecotone area between the Amazon and Brazilian Cerrado phytogeographic domain and acts as an ecological corridor (called the Araguaia-Bananal) that connects these areas, as well as the Caatinga and coastal environment (ICMbio 2019). The Brazilian
Cerrado phytogeographic domain it has high floristic diversity, including a third of the biodiversity in Brazil and around 5\% in the world (Klink \& Machado 2005).

The protected area Chapada das Mesas National Park, created under the decree of 12 December 2005 (BRASIL 2005), mainly has phytophysiognomic features of Brazilian Cerrado, including large formations of grassland and savanna, as well as natural ecosystems of high ecological and socio-environmental value (ICMbio 2019). Despite being established over a decade ago and its ecological relevance, there are few published works about the plant biodiversity that support the creation of a management plan for the area (Oliveira et al. 2018, Silva et al. 2018).

The phytogeographic domain in Maranhão State are under an accelerated process of destruction (Bolfe et al. 2016, Silva Junior et al. 2018) and studying the floristic diversity of the state is important since it is poorly sampled (Flora do Brasil 2020, under construction).

Thus, the objective of the present study was to inventory and provide a taxonomic treatment of the lycophyte species in Chapada das Mesas National Park, Maranhão State, Brazil.

\section{Material and Methods}

\section{Study area}

The study area, Chapada das Mesas National Park, comprises approximately 160,000 ha of Cerrado divided into two polygons, one with around 120,000 ha and another with about 40,000 ha, distributed in the municipalities of Carolina, Riachão and Estreito in southeastern Maranhão State (ICMbio 2019).

The climate is predominantly seasonal tropical, type Aw (Köppen 1948), with a dry season for 3 to 5 months and a rainy season with average rainfall ranging from 1,250 to $1,500 \mathrm{~mm}$, an average annual temperature between $20^{\circ} \mathrm{C}$ and $27^{\circ} \mathrm{C}$ and average relative air humidity of approximately $60 \%$ (Pereira et al. 2011).

Hydrologically, the area is very rich. The main water courses are the Farinha River (norther portion) and Itapecuru River (southern portion), there are over 400 springs in the interior, and along the courses there are well-conserved gallery forests (ICMBio 2019).

The relief is characterized by the presence of sandstone and typical forms of paleokarst in sandstone (e.g., hilltop arches, small cavities, canyons, paleosinkholes, sinkholes and river resurgences), which is closely related to the evolution of the subterranean drainage and river incision (Martins et al. 2017). The soil is predominantly sandy, where there are the Brazilian Cerrado sensu stricto and campo sujo physiognomies. However, there are also places with richer soils, mainly on the tops of mountains that have patches of semideciduous forest (ICMBio 2019).

In addition to the natural vegetation cover typical of the Brazilian Cerrado phytogeographic domain that contains many phytophysiognomies, among which savanna and forest aspects are notable, there are also Caatinga and Amazonian species, which help characterize the high diversity of the area (ICMBio 2019). These vegetation characteristics, including the presence of well-conserved gallery forests along water courses, large patches of cerradão and other types of phytophysiognomies, are essential for maintaining the biodiversity in the region (Marques 2012). 


\section{Data collection}

Samples of lycophytes were collected in Chapada das Mesas National Park and the surrounding area under permit number 50167-4 issued by the Sistema de Autorização e Informação em Biodiversidade do Instituto Chico Mendes de Conservação da Biodiversidade- Sisbio/ ICMBio.

The species were collected during three expeditions, in March and October 2017, and June 2018, which were three days each and included the dry and rainy seasons. Collecting was based on the methods proposed by Filgueiras et al. (1994). Microenvironments in the study area were selected and explored randomly, with the goal of visiting the greatest number of microenvironments where taxa might occur. The sampling points were mapped (Figure 1).

Herbarium specimens were made base on standard techniques used for seedless vascular plants (Silva 1989, Windisch 1992). All the material was deposited in the herbarium CCAA (RBH 2019), at the Federal University of Maranhão, Campus Chapadinha. When available, duplicates were sent to the following institutions: MG, HBRA and BHCB (Thiers 2019).

The identification and distribution of the species and genera were based on specialized literature, such as Alston et al. (1981), Fraile et al. (1995), Øllgaard (1995 A, B), Smith (1995), Hirai \& Prado (2000),
Góes-Neto et al. (2016), Heringer et al. (2016), Øllgaard \& Windisch (2016), Flora do Brasil 2020 (under construction), as well as revisions and neotropical floras (e.g., Tryon \& Stolze 1994, Moran \& Riba 1995, Mickel \& Smith 2004). When needed, some species were sent to specialists to confirm the identification. The morphological study, inspection and descriptions were based only on examined material (see results).

The terminology follows Lellinger (2002). Family and genus delimitations are based on PPG I (2016). Nomenclature and authors of the species follow the International Plant Names Index (IPNI 2019) and Tropicos (2019).

\section{Results}

\section{Diversity}

Six species of lycophytes were recorded in Chapada das Mesas National Park, including three families and three genera: Selaginellaceae with 4 species, Selaginella conduplicata Spring, $S$. erythropus (Mart.) Spring, S. radiata (Aubl.) Baker and S. simplex Baker; Isoëtaceae, Isoëtes sp.; and Lycopodiaceae, Palhinaea cernuna (L.) Franco \& Vasc.

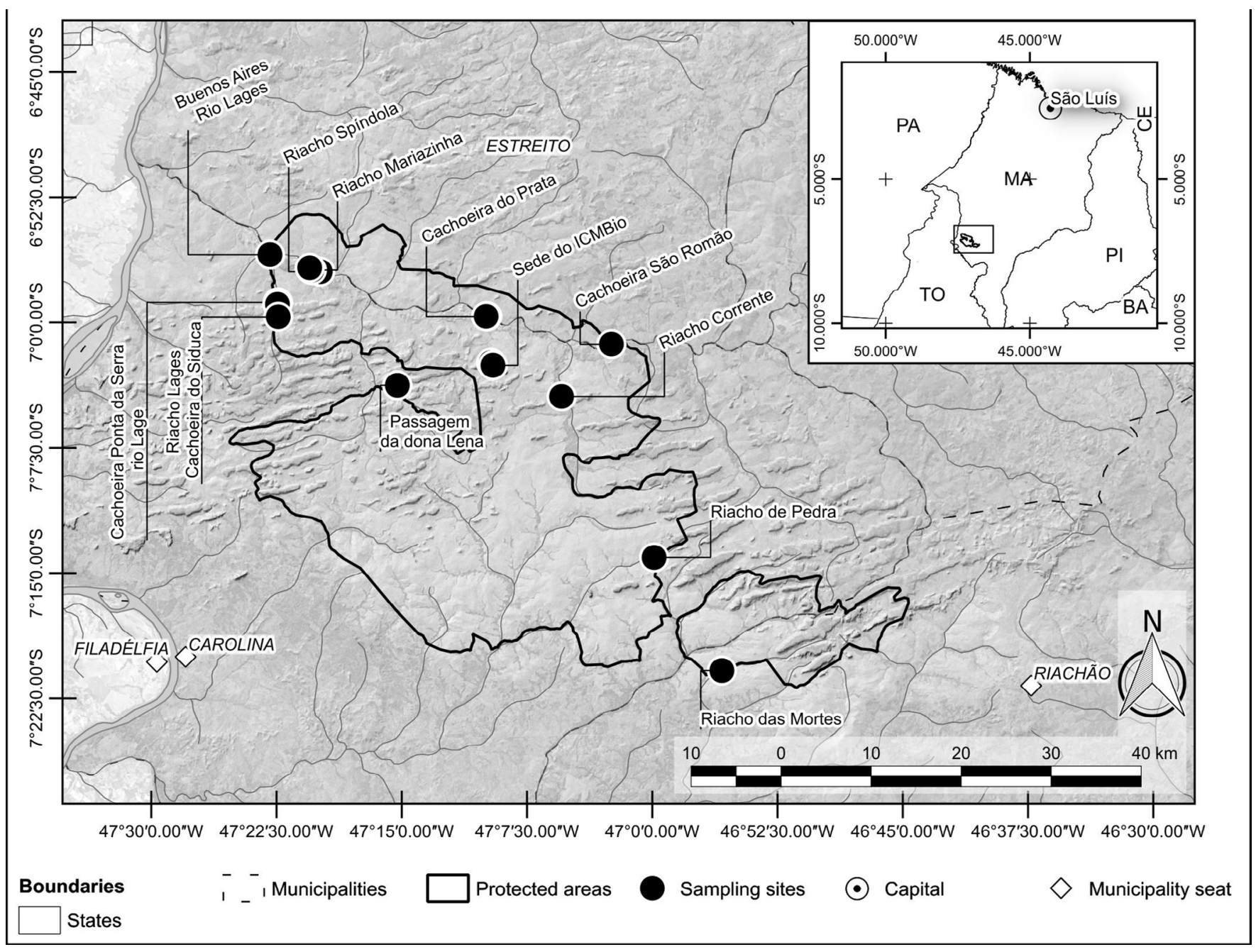

Figure 1. Collecting sites in the Chapada das Mesas National Park, Maranhão State, Brazil. 


\section{Identification key to the lycophyte species in Chapada das Mesas National Park}

1. Plant homosporous; microphylls arranged in alternate whorls, not ligulate, acicular; lateral branches patent; strobili pendent at the apex of branches....

Palhinhaea cernua

1'. Plant heterosporous; microphylls arranged in four rows or forming a rosette, ligulate, linear, lanceolate, ovate-lanceolate to ovate-elliptic; lateral branches not patent; strobili absent or erect at the apex of branches.

2. Microphylls linear, 9.5-21.5 cm long, with four air chambers in transversal section, deposited in the form of a rosette on a corm stem type; sporangia fused in the base of the sporophyll .Isoëtes sp.

2'. Microphylls not linear $(<1 \mathrm{~cm}$ long), without air chambers in transversal section, arranged in four rows on aerial and prostrate branches; sporangia not fused, in strobili at the apex of branches.

3. Stem articulate; lateral microphylls with two denticulate auricles; base of dorsal microphylls with an auricle on the outer side; axillary microphylls with two dentate auricles with sparsely denticulate margin.

Selaginella conduplicata

3'. Stem not articulate; lateral microphylls without auricles; base of dorsal microphylls without auricles, rounded to slightly cuneate; axillary microphylls without auricles, truncate, rounded or sometimes subcordate, margin ciliate to serrate, rarely entire

4. Base of stem reddish; dorsal microphylls with ciliate margin; axillary microphylls with acuminate to attenuate apex.

Selaginella erythropus

4'. Base of stem stramineous; dorsal microphylls with denticulate-eciliate margin; axillary microphylls with acute apex.

5. Lateral microphylls with ciliate margin on the basal acroscopic side; dorsal microphylls with strongly aristate apex; axillary microphylls with ciliate margin at the base.

Selaginella radiata

5'. Lateral microphylls with denticulate margin on the basal acroscopic side; dorsal microphylls with acuminate to long-acuminate apex; axillary microphylls with sparsely serrate-eciliate margin.

..Selaginella simplex

\section{Taxonomic treatment, distribution and comments}

Palhinhaea Franco \& Vasc., Bol. Soc. Brot., sér. 2, 41: 24. 1967.

The genus is represented by 25 species (PPG I 2016). In Brazil, there are six species, which occur in all five regions politic and in the Amazon, Brazilian Cerrado, Atlantic Forest, Pampa and Pantanal phytogeographic domain. Of these, two species have been recorded in the Northeast Region and one in Maranhão.

1. Palhinhaea cernua (L.) Franco \& Vasc., Bol. Soc. Brot., sér. 2, 41: 25. 1967 .

Plant terrestrial or rupicolous, 47.5-187 cm long. Stem erect to long-scandent, flagelliform at the apex, stoloniferous, greenish to stramineous, glabrous; lateral branches dichotomously branched, lateral branches patent; terminal branches $4-5 \mathrm{~mm}$ wide (including microphylls); sterile microphylls isophyllous, microphylls arranged in alternate whorls, 3-4 mm long, acicular, gradually changing on the main axis from reflexed to patent, curved in the direction of the apex, apex cuneate, base decurrent, margin entire, glabrous or with sparse trichomes; strobili 3-20 × 1-2 mm, pendent at the apex of lateral branches; sporophylls $1.5-2 \mathrm{~mm}$ long, ovate-deltoid, apex long- cuspidate to acuminate, base coalescent, margin erose to laciniate; not ligulate; plant homosporous.

Specimens examined: BRAZIL, MARANHÃO, PARNA Chapada das Mesas, Carolina, Cachoeira da Ponta da Serra, Riacho Lages, 658'47,4" S, 47²2'25”' W, 235 m, 11 de March de 2017, L.R. Silva \& M.R. Pietrobom 31 (CCAA807); idem, L.R. Silva \& M.R. Pietrobom 78 (CCAA806); idem, Riacho Corrente, 704'25,6” S, 4705'26,6" W, 284 m, 13 de March de 2017, F.C. Almeida et al. 71 (CCAA854); idem, 704'25,0” S, 4705'26,2” W, 277 m, 7 de June de 2018, F.C. Almeida et al. 75 (CCAA855).

Distribution: The species has a Pantropical distribution (Øllgaard \& Windisch 2016) and occurs in Asia, Africa, the Antilles, Belize, Bolivia, Brazil, Cameroon, Costa Rica, Colombia, El Salvador, United States of America, Ecuador, Guatemala, Guinea, Honduras, Madagascar, Mexico, Nicaragua, Oceania, Paraguay, Peru, Suriname, Trinidad, and Venezuela (Øllgaard 1995B). In Brazil, it is widely distributed and occurs in all of the regions: North (Amazonas, Amapá, Pará, Rondônia, Roraima, Tocantins); Northeast (Alagoas, Bahia, Ceará, Maranhão, Paraíba, Pernambuco); Central-West (Distrito Federal, Goiás, Mato Grosso do Sul, Mato Grosso); Southeast (Espírito Santo, Minas Gerais, Rio de Janeiro, São Paulo); and South (Paraná, Rio Grande do Sul, Santa Catarina). 
Comments: Palhinhaea cernua is characterized by its dichotomously branched, patent lateral branches and pendent strobili. The strobili have been described as being 4-20 mm long and 2.5-3 mm wide (Øllgaard 1995A, Øllgaard \& Windisch 2016); however, in the samples examined from Chapada das Mesas National Park variations starting at $3 \mathrm{~mm}$ long and $1-2 \mathrm{~mm}$ wide were recorded.

The most similar species to $P$. cernua that also occurs in the Northeast Region is P. camporum (B. Øllg. \& P.G. Windisch) Holub, since it has an erect, branched stem and pendent strobili. However, P. cernua has recurved distal branches and a more flexible stem, while $P$. camporum has nonrecurved distal branches and a rigid stem (Øllgaard \& Windisch 2016).

In the study area, P. cernua was collected in an open environment, with a lot of or little sun, on soil and rock near a stream and waterfall.

Isoëtes L., Sp. Pl. 2: 1100. 1753.

The genus is represented by around 250 species (PPG I 2016). In Brazil, 28 species have been recorded, which are distributed in the five regions in the Amazon, Brazilian Cerrado, Altantic Forest, Pampa and Pantanal phytogeographic domain. From these 28 species, three have been recorded for the Northeast Region, Isoëtes gigantea $\mathrm{U}$. Weber, I. luetzelburgii U. Weber, I. panamensis Maxon \& C. V. Morton, the latter one also for Maranhão.

\section{Isoëtes sp.}

(Figure 2F)

Plant amphibious, $10.2-22.3 \mathrm{~cm}$ long. Stem globose, corm type, 2-3 lobate; microphylls imbricate, forming a rosette, with four air chambers in transversal section, deposited in the form of a rosette, 9.5-21.5 cm long, linear, erect, laminated, subula distal and with wings restricted to the proximal portion, septum with stellate, greenish cells; strobili absent; sporangia fused in the base of the sporophyll; megaspores trilete, distal and proximal surfaces baculate, whitish; plant heterosporous.

Specimens examined: BRAZIL, MARANHÃO, PARNA Chapada das Mesas, Carolina, Cachoeira do Prata, Rio Farinha, 659'36,9” S, 479'58,5" W, 198 m, 12 March 2017, L.R. Silva \& M.R. Pietrobom 45 (CCAA808).

Comments: The material collected of Isoëtes is sterile, but 4 or 5 megaspores were found loose in the substrate near the stem. Thus, even by a specialist, it is not possible to determine the species (personal communication by Dr. Jovani Bernardino de Sousa Pereira) since the taxonomy of the group is mainly based on reproductive structures, such as sporangia and spores (Hickey 1986). The specimen analyzed is similar to Isoëtes panamensis Maxon \& C.V.Mort in microphyll and megaspore characters, such as the presence of hyaline wings on the proximal portion of the microphyll, triquetrous subula and baculate surface of the megaspore. However, additional collections are needed to confirm the species.

In the study area, it was collected in an open, sunny environment near a waterfall, growing as an amphibious plant where there is seasonal flooding.

Selaginella P. Beauv. Mag. Encycl. 9(5): 478. 1804.

The genus is represented by around 700 species (PPG I 2016). In Brazil, 96 species have been recorded, which are distributed in the five regions of the country and in the Amazon, Caatinga, Brazilian Cerrado, Atlantic Forest and Pantanal phytogeographic domain. Of these, 22 species are cited for the Northeast region and four are cited for Maranhão.

\section{Selaginella conduplicata Spring, Fl. Bras. 1(2): 129. 1840.}

(Figures 2A; 3A-C)

Plant terrestrial or rupicolous, $10-130 \mathrm{~mm}$ long. Stem articulate, 2-4(-5)-pinnate, not flagelliform, repent to erect, not stoloniferous, stramineous at the base, glabrous, distal branches 3-4(-5) mm wide (including microphyll); dorsal rhizophores throughout the extension of the decumbent stem, stramineous; microphylls not overlapping before the first bifurcation, heterophyllous; microphylls not linear, without air chambers in transversal section, microphylls arranged in four rows on aerial and prostrate branches; lateral microphylls arranged in two rows, 2-3(-4) mm long, lanceolate, ascending, apex acute, base with two denticulate auricles, smaller auricle on the external acroscopic margin widely denticulate, whitish, basioscopic margin entire to rarely widely denticulate in the direction of the apex, basioscopically greenish; dorsal microphylls arranged in two rows, $1-2.5(-3) \mathrm{mm}$ long, ovatelanceolate, asymmetric, apex long-acute to acuminate, base with one denticulate auricle on the external side, margin sparsely denticulate, whitish; axillary microphylls $1.5-2.5 \mathrm{~mm}$ long, lanceolate, apex acute, base with two long, dentate auricles, margin sparsely denticulate, whitish; strobili erect at the apex of branches, 3-15 mm long; sporangia not fused, in strobili at the apex of branches; megasporophylls 1(2), at the base of the strobilus; megaspores white; plant heterosporous.

Specimens examined: BRAZIL, MARANHÃO, PARNA Chapada das Mesas, Carolina, Cachoeira do Prata, Rio Farinha, 659’36,9” S, 479'58,5” W, 198 m, 12 March 2017, L.R. Silva \& M.R. Pietrobom 40 (CCAA820); idem, L.R. Silva \& M.R. Pietrobom 43 (CCAA814); idem, 659'37,4” S, 4709'58,0” W, 194 m, 29 October 2017, L.R. Silva \& F.C. Almeida 84 (CCAA826); idem, 6059'37' S, 4709'57' W, 197 m, 6 June 2018, F.C. Almeida et al. 03 (CCAA852); idem, 659'36,7' S, 4709'53,1" W, 210 m, F.C. Almeida et al. 29 (CCAA853).

Distribution: This species has a South American distribution, including Brazil, Guyana, French Guiana, Suriname, Colombia, and Peru (Alston et al. 1981, Smith 1995). In Brazil, it is cited for the North (Acre, Amapá, Amazonas, Pará, Roraima), Northeast (Ceará, Pernambuco), and Central-West (Mato Grosso) regions (Paula-Zárate 2005, Silva 2014). This is the first record of Selaginella conduplicata for the Brazilian Cerrado and the state of Maranhão.

Comments: Selaginella conduplicata differs from the other species collected in the study area by its articulate stem, microphylls with auricles, and presence of one megasporangium (rarely two) on the strobili.

In the study area, it was collected near a waterfall, in an open to partially shaded environment, and was rupicolous or sometimes terrestrial.

2. Selaginella erythropus (Mart.) Spring, Fl. Bras. 1(2): 125. 1840. (Figures 2B; 3D-F)

Plant terrestrial or rupicolous, 15-170 mm long. Stem not articulate, 2-3-pinnate, flagelliform, erect, stoloniferous, reddish 

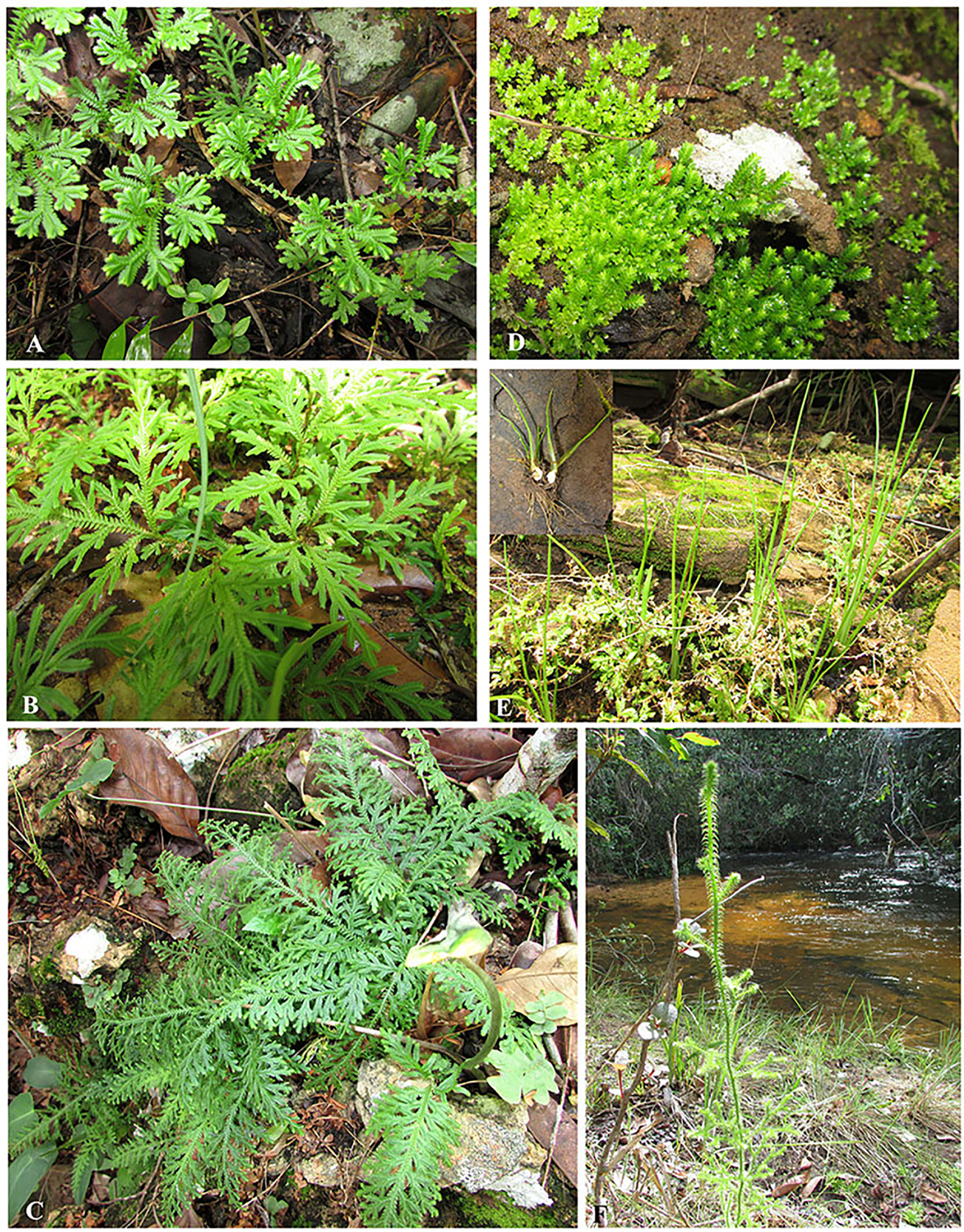

Figure 2. Habitat of the lycophytes in Chapada das Mesas National Park. A. Selaginella conduplicata. B. Selaginella erythropus. C. Selaginella radiata. D. Selaginella simplex. E. Isoëtes sp. F. Palhinhaea cernua. Photos: Laryssa Reis. 
at the base, glabrous, distal branches $1.5-2 \mathrm{~mm}$ wide (including microphylls); ventral rhizophores present on the lower half of the erect stem, reddish; microphylls overlapping before the first bifurcation, isophyllous at the base, heterophyllous above the first bifurcation; microphylls not linear, without air chambers in transversal section, microphylls arranged in four rows on aerial branches; lateral microphylls arranged in two rows, $1.8-2 \mathrm{~mm}$ long, lanceolate to ovate-lanceolate, slightly falcate, slightly ascending at the apex, apex acuminate to attenuate, base truncate, slightly rounded acroscopically, not auriculate, acroscopic and basioscopic margins ciliate to serrate, rarely entire, slightly hyaline; dorsal microphylls arranged in two rows, $1-1.5 \mathrm{~mm}$ long, ovate-lanceolate, symmetric, apex long-aristate to long-acuminate, base rounded, margin ciliate to long-dentate, hyaline to slightly hyaline; axillary microphylls $(1.2-) 1.8-2 \mathrm{~mm}$ long, similar to lateral microphylls, apex acuminate, base rounded or sometimes slightly truncate on the acroscopic or basioscopic side, not auriculate, margin ciliate to denticulate, serrate toward the apex, greenish; strobili erect at the apex of branches, (1-)2-5(-6) $\mathrm{mm}$ long; sporangia not fused, in strobili at the apex of branches; megasporophylls ventral, throughout the extension of the strobilus; megaspores white; plant heterosporous.

Specimens examined: BRAZIL, MARANHÃO, PARNA Chapada das Mesas, Carolina, Cachoeira do Prata, Rio Farinha, 659’36,9” S, 479'58,5" W, 198 m, 12 March 2017, L.R. Silva \& M.R. Pietrobom 39 (CCAA819); idem, 659'41,3" S, 4709'57,4” W, 213 m, L.R. Silva \& M.R. Pietrobom 37 (CCAA818); idem, 659'37,4” S, 4709'58,0” W, 194 m, 29 October 2017, L.R. Silva \& F.C. Almeida 90 (CCAA823); idem, L.R. Silva \& F.C. Almeida 91 (CCAA825); idem, 659'37,3" S, 4709'58,0" W, L.R. Silva \& F.C. Almeida 100 (CCAA824); idem, 6059'37' S, 4709'57' W, 197 m, 6 June 2018, F.C. Almeida et al. 08 (CCAA851); F.C. Almeida et al. 09 (CCAA859); F.C. Almeida et al. 14 (CCAA846); idem, Cachoeira São Romão, 701'15,4” S, 4702'28,2” W, 241 m, 31 October 2017, L.R. Silva \& F.C. Almeida 183 (CCAA822); idem, 701'17,1" S, 4702'27,1”'W, 256 m, 7 June 2018, F.C. Almeida et al. 65 (CCAA847); idem, Cachoeira Ponta da Serra, Riacho Lages, 658'47,4” S, 47²2’25” W, 235 m, 11 March 2017, L.R. Silva \& M.R. Pietrobom 24 (CCAA817); idem, L.R. Silva \& M.R. Pietrobom 29 (CCAA816); idem, Estreito, Cachoeira do Prata, Rio Farinha, 6 59'36,7” S, 479'53,1” W, 210 m, 6 June 2018, F.C. Almeida et al. 26 (CCAA849); idem, F.C. Almeida et al. 28 (CCAA848).

Distribution: This species has a neotropical distribution, including Costa Rica, Colombia, Ecuador, Peru, Bolivia, and Brazil (Fraile et al. 1995). For Brazil, it is cited for the North (Pará, Tocantins, according to Góes-Neto 2016), Northeast (Bahia, Ceará, Maranhão, Paraíba, Piauí, Rio Grande do Norte), Central-West (Distrito Federal, Goiás, Mato Grosso, Mato Grosso do Sul) and Southeast (Minas Gerais, Rio de Janeiro) regions.

Comments: The main characteristics of Selaginella erythropus are the reddish stem and overlapping microphylls before the first bifurcation (Fraile et al. 1995). Among the material analyzed, on some specimens there was a stolon emerging at the apex of the branches; however, according to Fraile et al. (1995), the stolons of S. erythropus are restricted to the base of the branches.

In the study area, this species was collected near a waterfall and margin of a river, in an open or sometimes partially shaded environment, mostly as a rupicolous plant.

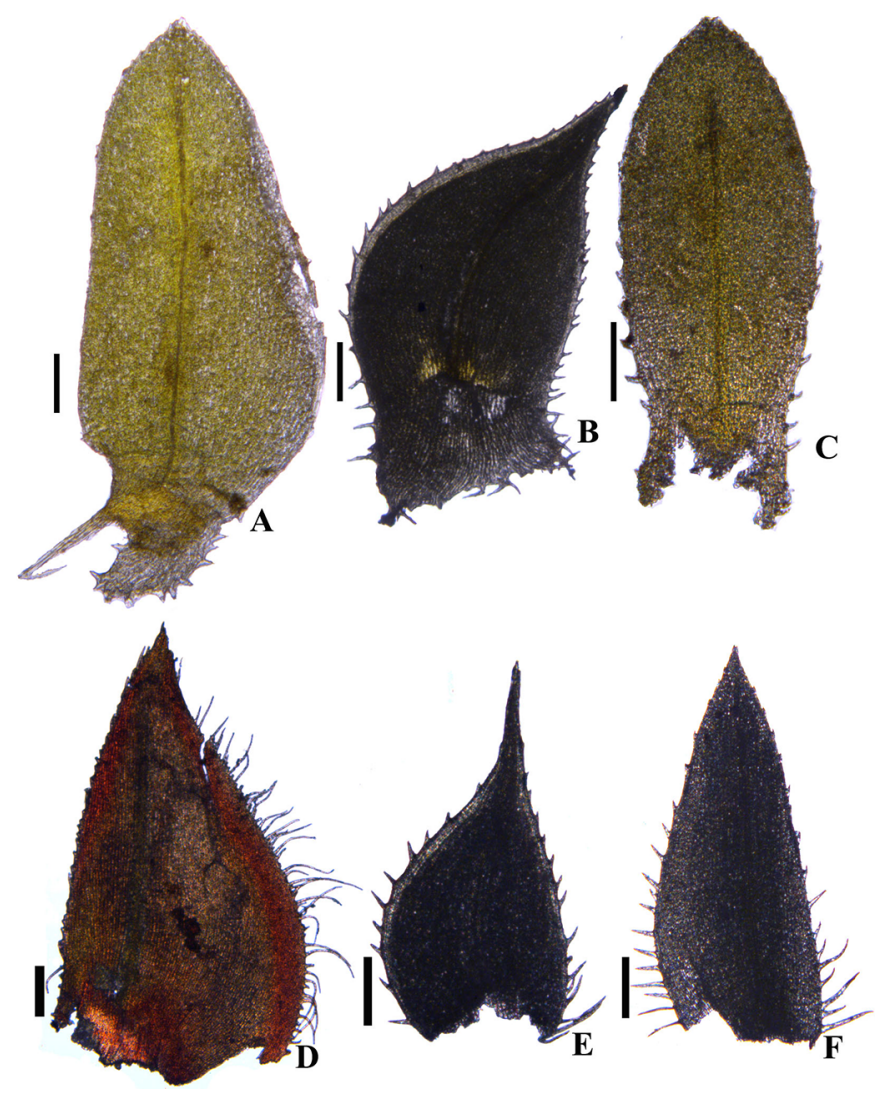

Figure 3. A-C. Selaginella conduplicata (F.C. Almeida et al. 03 (CCAA852)). A. Lateral microphyll. B. Dorsal microphyll. C. Axillary microphyll. D-F. Selaginella erythropus (L.R. Silva \& M.R. Pietrobom 39 (CCAA819)). D. Lateral microphyll. E. Dorsal microphyll. F. Axillary microphyll. Photos: Samuel Vieira Brito.

3. Selaginella radiata (Aubl.) Spring, Bull. Acad. Roy. Sci. Bruxelles 10: 143, no. 54. 1843.

(Figures 2C; 4A-C)

Plant terrestrial or rupicolous, 15-205 mm long. Stem not articulate, 2-3-pinnate, not flagelliform, erect, stoloniferous, stramineous, glabrous, distal branches 3-10 mm wide (including microphylls); rhizophores abaxial, only at the base of the main stem, stramineous; microphylls not overlapping before the first bifurcation, anisophyllous; microphylls not linear, without air chambers in transversal section, microphylls arranged in four rows on aerial branches; lateral microphylls arranged in two rows, (1.2-)2-2.8 mm long, ovate-lanceolate, ascending, apex acute, base cordate, not auriculate, basal acroscopic margin strongly ciliate and serrate toward the apex, basioscopic margin slightly serrate, greenish; dorsal microphylls arranged in two rows, (1-)1.5-2 mm long, ovateelliptic, asymmetric, apex strongly aristate, base slightly cuneate, margin denticulate, denticles larger at the base on the acroscopic side, hyaline; axillary microphylls (1.3-)1.5-2(-2.1) mm long, lanceolate, apex acute, base truncate, not auriculate, margin ciliate in the proximal region and slightly serrate toward the apex, hyaline at the base and greenish toward the apex; strobili erect at the apex of branches, 2-6 mm long; sporangia not fused, in strobili at the apex of branches; megasporophylls $2(-4)$, at the base of the strobilus; megaspores whitish; plant heterosporous.

Specimens examined: BRAZIL, MARANHÃO, PARNA Chapada das Mesas, Estreito, Cachoeira do Prata, Rio Farinha, 659'36,7' S, 
479'53,1" W, 210 m, 12 March 2017, L.R. Silva \& M.R. Pietrobom 47 (CCAA809); idem, Carolina, Cachoeira São Romão, 7¹'17,2” S, 47²'27,8” W, 258 m, 13 March 2017, L.R. Silva \& M.R. Pietrobom 55 (CCAA815); idem, L.R. Silva \& M.R. Pietrobom 59 (CCAA811); idem Cachoeira São Romão, Rio Farinhas, $7^{\circ} 01^{\prime} 17,1^{\prime \prime}$ S, 4702'27,1" W, 256 m, 7 June 2018, F.C. Almeida et al. 47 (CCAA839); idem, Cachoeira Ponta da Serra, Rio Lages, 658'47,4” S, 47²2’25” W, 235 m, 11 March 2017, L.R. Silva \& M.R. Pietrobom 22 (CCAA810); idem, 658'47,1" S, 47²2'25,5”'W, 238 m, 8 June 2018, F.C. Almeida et al. 114 (CCAA840); idem, Pousada Mansinha, riacho da Mansinha, $7^{\circ} 07^{\prime} 36,5$ " S, 47²5'18,2” W, $286 \mathrm{~m}, 8$ June 2018 F.C. Almeida et al. 120 (CCAA842); idem, F.C. Almeida et al. 126 (CCAA841).

Distribution: This species is distributed in South America, including Brazil, Bolivia, Colombia, Ecuador, Guyana, French Guiana, Peru, Suriname and Venezuela (Alston et al. 1981). In Brazil, it has been recorded in the North (Amapá, Amazonas, Pará, Rondônia), Northeast (Bahia, Maranhão, Piauí), and Central-West (Mato Grosso) regions (Góes-Neto et al. 2016). This is the first record of Selaginella radiata for the Brazilian Cerrado.

Comments: Selaginella radiata is characterized by the base of the lateral and axillary microphylls strongly ciliate, as well as strongly aristate dorsal microphylls. Selaginella decomposita Spring is similar to $S$. radiata because of the non-articulate stem, non-auriculate microphylls and aristate dorsal microphylls. However, $S$. decomposita differs from $S$. radiata by the denticulate lateral and axillary microphyll bases and acuminate to slightly aristate dorsal microphylls (Hirai \& Prado 2000, Heringer et al. 2016).

In the study area, $S$. radiata was collected near a waterfall and source of streams, in an open environment and less often in the shade, as a rupicolous and rarely terrestrial plant on sandy slopes.

4. Selaginella simplex Baker, J. Bot. 23: 293, no. 304. 1885.

(Figures 2D; 4D-F)

Plant terrestrial or rupicolous, 10-28 mm long. Stem not articulate, 1-2 pinnate, not flagelliform, suberect, not stoloniferous, stramineous, glabrous, distal branches 1.8-2 mm wide (including microphylls); rhizophores adaxial, restricted to the basal part of the stem, stramineous; microphylls not overlapping before the first bifurcation, heterophyllous; microphylls not linear, without air chambers in transversal section, microphylls arranged in four rows on aerial branches; lateral microphylls arranged in two rows, 1.2-2 mm long, ovate to ovate-elliptic, ascending, apex acute, base rounded, not auriculate, acroscopic margin denticulate at the base and serrate toward the apex, greenish, basioscopic margin serrate on the apical half; dorsal microphylls arranged in two rows, $1-1.2 \mathrm{~mm}$ long, ovate-lanceolate to ovate-elliptic, asymmetric, apex acuminate to long-acuminate, base rounded to slightly cuneate, margin denticulate, greenish; axillary microphylls 1.2-2 mm long, ovate-elliptic, apex acute, base rounded to subcordate, not auriculate, margin sparsely serrate, greenish; strobili erect at the apex of branches, (2-)3-10(-13) mm long; megasporophylls numerous, ventral at the base of the strobilus; sporangia not fused, in strobili at the apex of branches; megaspores yellow; plant heterosporous.

Specimens examined: BRAZIL, MARANHÃO, PARNA Chapada das Mesas, Estreito, Cachoeira do Prata, Rio Farinha, ca. 659'36,7' S, 479'53,1" W, 210 m, 6 June 2018, F.C. Almeida et al. 25 (CCAA845); idem, F.C. Almeida et al. 27 (CCAA843); idem, F.C. Almeida et al. 30
(CCAA844); idem, 12 March 2017, L.R. Silva \& M.R. Pietrobom 46 (CCAA813); idem, L.R. Silva \& M.R. Pietrobom 48 (CCAA812); idem, Carolina, Cachoeira São Romão, 7¹'17,2” S, 47²'27,8” W, 258 m, 13 March 2017, L.R. Silva \& M.R. Pietrobom 58 (CCAA821).

Distribution: This species has a neotropical distribution, including Brazil, Bolivia, Costa Rica, Mexico, Trinidad and Tobago, and Venezuela (Alston et al. 1981, Fraile et al. 1995). In Brazil, it occurs in the North (Pará, Tocantins), Northeast (Bahia, Ceará, Maranhão Piauí, Pernambuco, Sergipe), and Central-West (Goiás, Mato Grosso) regions (Góes-Neto et al. 2016).

Comments: Selaginella simplex is similar to S. minima because of the lateral microphylls with a rounded base and acute apex. However, it has greenish microphyll margins, dorsal microphylls with a rounded to slightly cuneate base and a yellow megaspore, while $S$. minima has hyaline microphyll margins, dorsal microphylls with an auricle on the external side and a white megaspore (Fraile et al. 1995). Both Selaginella simplex and S. minima Baker are neotropical, but $S$. minima occurs in Argentina, Guyana, French Guiana, Honduras, Nicaragua and Panama, where $S$. simplex has not been recorded. In Brazil, both species occur in the North and Central-West regions, while only S. simplex occurs in the Northeast Region (Alston et al. 1981, Fraile et al. 1995, Flora do Brasil 2020, under construction).

In the study area, S. simplex was collected as a rupicolous plant, both in open and shaded environments. Some individuals grow with leafy liverworts.

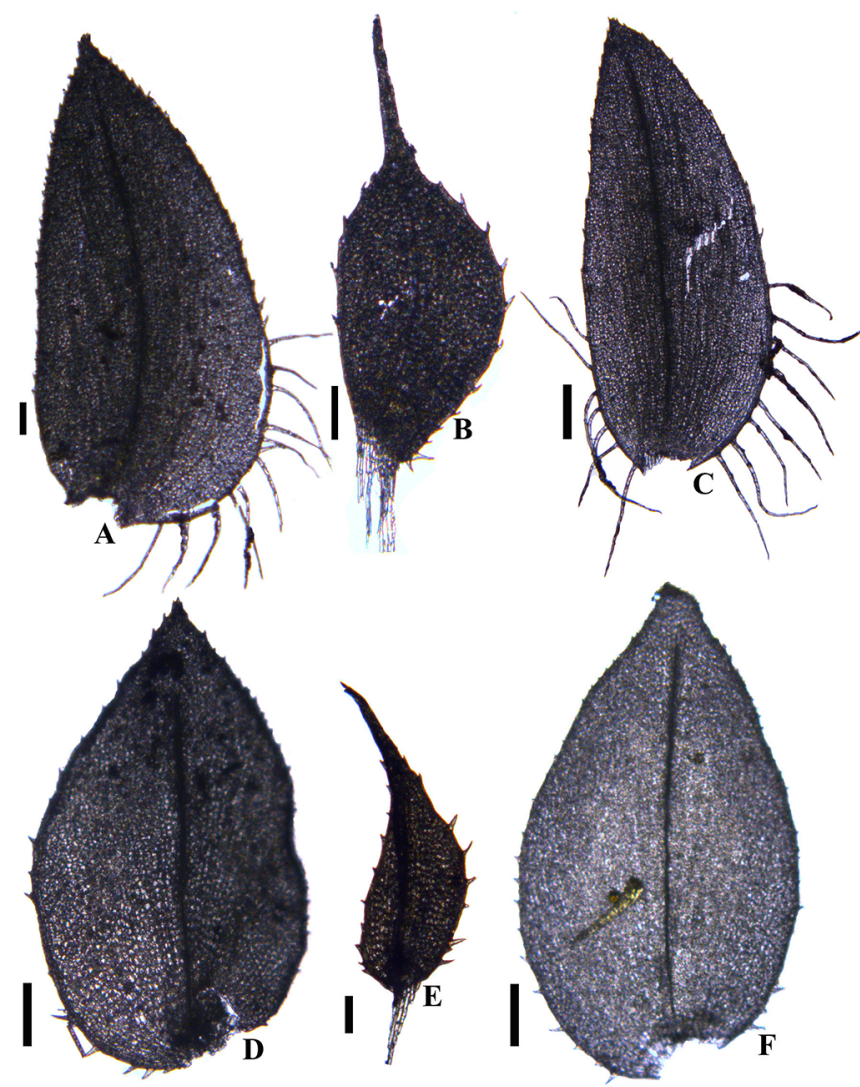

Figure 4. A-C. Selaginella radiata (L.R. Silva \& M.R. Pietrobom 47 (CCAA809)). A. Lateral microphyll. B. Dorsal microphyll. C. Axillary microphyll. D-F. Selaginella simplex (F.C. Almeida et al. 25 (CCAA845)). D. Lateral microphyll. E. Dorsal microphyll. F. Axillary microphyll. Photos: Samuel Vieira Brito. 


\section{Discussion}

This inventory has around $22 \%$ of the species recorded for the Brazilian Cerrado (Flora do Brasil 2020 under construction). The diversity of lycophytes listed in this work (six species) is greater in number of families and species than recorded by Bastos \& Cutrim (1999), Fernandes et al. (2010), Conceição \& Rodrigues (2010), Silva et al. (2017) Santos-Silva et al. (2018), which cite between one or three species, in the Lycopodiaceae and Selaginellaceae. The other published studies conducted in the Maranhão state did not record lycophytes (e.g. Fernandes et al. 2007, Conceição \& Ruggieri 2010, Conceição et al. 2015, Santos-Silva et al. 2019).

This study reports an increase in the distribution of two species in the Brazilian Cerrado, S. conduplicata and $S$. radiata of which the first species is a new record for Maranhão State. Starting in 2015, there has been an increase in the number of studies about the Brazilian Cerrado, which has resulted in an increase in the number of lycophyte and fern species known for the phytogeographic domain (see BGF 2018). However, the known diversity for Maranhão State is still low. It is thought that the diversity of the state is greater than estimated, since it is a transition area between phytogeographic domain (mainly the Brazilian Cerrado and Amazon). Thus, there should be more and systematic sampling of the environments in this region.

Most of the species cataloged in this study are widely distributed in nearly all phytogeographic domain, such as Palhinhaea cernua (Amazon, Brazilian Cerrado, Atlantic Forest, as well as mangrove ecosystems), Selaginella erythropus (Caatinga, Brazilian Cerrado, Atlantic Forest,), S. simplex (Amazon, Caatinga, Brazilian Cerrado) (Bastos \& Cutrim 1999, Azevedo \& Silva 2001, Pietrobom \& Barros 2003, Fernandes et al. 2007, Maciel et al. 2007, Conceição \& Rodrigues 2010, Fernandes et al. 2010, Prado \& Sylvestre 2010, Barros 2013, Santiago et al. 2014, Farias et al. 2017, Prado \& Sylvestre 2010, Silvestre et al. 2019). The exception is $S$. conduplicata that, until now, was cited to Amazonia and Atlantic Forest in Northeastern (Ceará e Pernambuco) (Silva 2014). However, in this study it was collected in Brazilian Cerrado.

In the study area, the phytophysiognomy with the greatest diversity of species was riparian forest. According to Lehn et al. (2018), this environment is typical of the Brazilian Cerrado phytogeographic domain and favors the establishment of these species. According to Silvestre (2018), independent areas of humid forest, characteristic of transition areas, are points of species exchange, which is corroborated by the distribution of lycophytes and ferns in the region.

The Brazilian Cerrado in the Northeast Region contains ecotones, which is reflected in the floristic diversity of these areas (Walter 2006) that exhibit heterogeneous vegetation, such as gallery forest or riparian forest, and rocky outcrop vegetation (Eiten 1994). In a study of the vascular flora by Mendonça et al. (2008), it was estimated that the phytogeographic domain of the Brazilian Cerrado contains 390 taxa of seedless vascular plants in its diverse phytophysiognomies. Of this total, a little more than half occur in forest formations, and less than $8 \%$ occur in rocky environments and on the edges of streams and rivers, where nearly all of the taxa listed here occur. Further, compared to the present study, pioneering works about this Brazilian Cerrado that treat the floristic composition of lycophytes and ferns (e.g., Simabukuro et al. 1994, Forsthofer \& Athayde Filho 2012, Pallos et al. 2016) cite a lower diversity of lycophytes and have only two species in common: Selaginella erythropus and Palhinhaea cernua.

Therefore, given the relevance of the data presented here, the importance of this study in relation to the Brazilian Cerrado and Chapada das Mesas National Park is evident, mainly because it increases what is known about the floristics and taxonomy of lycophytes from the Brazilian Cerrado phytogeographic domain, contributing to the biodiversity knowledge of this Protection area, and, in the future, possibly allowing appropriate conservation strategies. It is important to emphasize that the Chapada das Mesas National Park comprises half (six species) of lycophyte's diversity recorded for the Maranhão state (twelve species including the results of this study). The other six species were not found in the Chapada das Mesas National Park during our survey: Lycopodiella geometra B.Øllg. \& P.G.Windisch, Pseudolycopodiella carnosa (Silveira) Holub, P. caroliniana (L.) Holub, P. meridionalis (Underw. \& Loyd) Holub, Selaginella flagellata Spring, S. marginata (Humb. \& Bonpl. ex Willd.) Spring (Fernandes et al. 2010, Conceição \& Rodrigues 2010, Santos-Silva et al. 2018, Flora do Brasil 2020, under construction). In addition, this protected area houses one species which had never been registered previously for the state, Selaginella conduplicata, and other species and genus possessing a restrict geographic distribution, such as: S. radiata and Isoëtes.

\section{Acknowledgments}

We thank the specialists Dr. Luiz Armando de Araújo Góes-Neto, for confirming the identification of some species of Selaginella, and Dr. Jovani Bernardino de Sousa Pereira, for examining the specimens of Isoëtes. We also thank Dr. Felipe Polivanov Ottoni and Dr. Fredgarson Costa Martins for helping to collect the material; Dr. Felipe Polivanov Ottoni for the critical revision of the manuscript before its submission; and Dr. Samuel Vieira Brito for helping with the photos. This project was financially supported by FAPEMA, Fundação de Amparo em Pesquisa do Estado do Maranhão (Processo universal nº 01271/2016).

\section{Author Contributions}

Francilene Cardoso Almeida: Contributed equally in all sections and processes of the manuscript.

Marcio Roberto Pietrobom: Contributed equally in all sections and processes of the manuscript.

Rozijane Santos Fernandes: Contributed equally in all sections and processes of the manuscript.

\section{Conflicts of Interest}

The authors declarethat they have no conflict of interest related to the publication of this manuscript.

\section{References}

ALSTON A.H.G., JERMY A.C. \& RANKIN J.M. 1981. The genus Selaginella in tropical South America. Bull. Brit. Mus. (Nat. Hist.) Bot. 9: 233-330.

ARANA, M. \& ØLLGAARD, B. 2012. Revisión de las Lycopodiaceae (Embryopsida, Lycopodiidae) de Argentina y Uruguay. Darwiniana. 50(1/2): 266-295.

ARANA, M.D., GONZALEZ, H.A., BONIFACINO, M. \& BRUSSA, C.A. 2017. A Revision of Lycopodiaceae from Uruguay. Int. J. Adv. Res. 3(4): 24-39. 
AZEVEDO, A.C.G. \& SILVA, W.M. 2001. Ocorrência de Lycopodiella cernua (L.) Pic. Serm. (Pteridophyta: Lycopodiopsida: Lycopodiaceae) nas bordas de manguezal, São Luís - Maranhão - Brasil. Bol. Lab. Hidrobiol. 14(1): 111-114.

BANKS, J.A. 2009. Selaginella and 400 million years of separation. Annu. Ver. Plant Biol. 60: 223-238.

BARROS, S.C.A. 2013. Similaridade e composição das samambaias e licófitas em fragmentos de floresta atlântica no nordeste do Brasil. Dissertação de mestrado, Universidade Estadual da Paraíba, Campina Grande.

BASTOS, C.C.C. \& CUTRIM, M.V.J. 1999. Pteridoflora da Reserva florestal do Sacavém, São Luis - Maranhão. Bol. Mus. Para. Emílio Goeldi, sér. Botânica 15(1): 3-37.

BFG - The Brazil Flora Group. 2018. Brazilian Flora 2020: Innovation and collaboration to meet Target 1 of the Global Strategy for Plant Conservation (GSPC). Rodriguésia 69(4): 1513-1527.

BOLFE, É.L., VICTÓRIA, D.C., CONTINI, E., BAYMA-SILVA, G., SPINELLI-ARAUJO, L. \& GOMES, D. 2016. Matopiba em crescimento agrícola aspectos territoriais e socioeconômicos. Rev. Polít. Agríc. 25(4): 38-62.

BRASIL. 2005. Decreto de 12 de Dezembro de 2005 http://www.planalto.gov. br/ccivil_03/_Ato2004-2006/2005/Dnn/Dnn10718.htm (último acesso em 28 Out 2019).

CONCEIÇÃO, G.M. \& RODRIGUES, M.S. 2010. Pteridófitas do Parque Estadual do Mirador, Maranhão, Brasil. Cad. Geociênc. (7): 47-53.

CONCEIÇÃO, G.M. \& RUGGIERI, A.C. 2010. Pteridófitas do município de Tufilândia, Estado do Maranhão, Brasil. Pesquisa em Foco 18(1): 59-68.

CONCEIÇÃO, G.M., PAULA-ZARATE, E.L., RUGGIERI, A.C., SILVA, E.O. \& SILVA, M.F. 2015. Pteridoflora e seus aspectos ecológicos no município de Timon, Maranhão, Brasil. Braz. Geogr. J. 6(1): 74-81.

EITEN, G. 1994. Duas travessias na vegetação do Maranhão. UNB, Brasília, p.76.

FARIAS, R., SILVA, I., PEREIRA, A.F, SANTIAGO, A. \& BARROS, I. 2017. Inventário de samambaias e licófitas da RPPN Pedra D'Antas, Pernambuco, nordeste do Brasil. Biota Neotrop. 17(4): e20170364. http: //dx.doi.org / 10.1590 / 1676-0611-BN-2017-0364

FERNANDES, R.S., CONCEIÇÃO, G.M., BRITO E.S. \& PAULA-ZÁRATE, E.L. 2007. Diversidade Florística de Pteridófitas da Área de Preservação Ambiental do Inhamum, Caxias, Maranhão, Brasil. Rev. bras. Bioci, 5(2): 411-413.

FERNANDES, R.S., CONCEICÃO, G.M., COSTA J.M. \& PAULA-ZÁRATE, E.L. 2010. Samambaias e licófitas do município de Caxias, Maranhão, Brasil. Bol. Mus. Emílio Goeldi. Ciênc. Nat. (3): 345-356.

FILGUEIRAS, T.S., NOGUEIRA, P.E., BROCHADO, A.L., \& GUALA, G.F., 1994. Caminhamento: um método expedito para levantamentos florísticos qualitativos. Cad. Geociênc. 12(1): 39-43.

FLORA DO BRASIL 2020. http://floradobrasil.jbrj.gov.br/ (último acesso em 28 Out 2019).

FORSTHOFER, M. \& ATHAYDE-FILHO, F.P. 2012. Florística e aspectos ecológicos de samambaias e licófitas ao longo do córrego cachoeirinha, Nova Xavantina-MT. Pesqui. Bot. 63: 149-164.

FRAILE, M.E., SOMERS, P. \& MORAN, R.C. 1995. Selaginella. In Psilotaceae a Salviniaceae (R.C. Moran \& R. Riba, eds). In Flora Mesoamericana (G. Davidse, M.S. Sousa \& S. Knapp, eds.). Universidad Nacional Autónoma de México, Ciudad de México, v.1, p.22-42.

GÓES-NETO, L.A.A. 2016. Estudos taxonômicos em Selaginellaceae Willk (Lycopodiophyta) no Brasil. Tese de doutorado. Universidade Federal de Minas Gerais. Belo Horizonte.

GÓES-NETO, L.A.A., PALLOS, J. \& SALINO, A. 2016. Flora das cangas da Serra dos Carajás, Pará, Brasil: Selaginellaceae. Rodriguésia 67(5) (Especial): 1177-1180.

HERINGER G., VALDESPINO I.A. \& SALINO, A. 2016 Selaginella P. Beauv. from Minas Gerais, Brazil. Acta Bot. Bras. 30(1): 60-77.

HICKEY, R.J. 1986. Morfologia da superfície de isóteos megaspore: variação da nomenclatura e importância sistemática. Am. Fern. J. 76: 1-16.
HIRAI R.Y. \& PRADO, J. 2000. Selaginellaceae Willk. no Estado de São Paulo, Brasil. Rev. bras. Bot. 23(3): 313-339.

ICMBIO. http://www.icmbio.gov.br (último acesso em 12 Agost. 2019).

IPNI. https://www.ipni.org/ (último acesso em: 06 Nov. 2019).

JERMY, A.C. 1990. Selaginellaceae. In The families and genera of vascular plants (K.U. Kramer \& P.S. Green, eds). Springer Verlag, Berlin, p.39-45.

KENRICK, P. \& CRANE, P.R. 1997. The origin and early diversification of land plants. Smithsonian Institution Press, Washington.

KLINK, C. A. \& MACHADO, R.B. 2005. A Conservação do Cerrado Brasileiro. Megadiversidade 1(1): 148-155.

KÖPPEN, W. 1948. Climatologia: con un estudio de los climas de la tierra. Fundo de Cultura Economica, México, p.478.

LEHN, C.R., ASSIS, E.L.M.D \& SALINO, A. 2018. Check-list das samambaias e licófitas do estado de Mato Grosso do Sul, Brasil. Iheringia, Sér. Bot. 73:255-263.

LELLINGER, D.B. 2002. A modern multilingual glossary for taxonomic pteridology. American Fern Society, Washington, p.263.

MACIEL, S., SOUZA, M.G.C. \& PIETROBOM, M.R. 2007. Licófitas e monilófitas do Bosque Rodrigues Alves Jardim Botânico da Amazônia, município de Belém, estado do Pará, Brasil. Bol. Mus. Para. Emílio Goeldi. Ciências Naturais 2(2): 69-83.

MARQUES, A.R. 2012. Saberes geográficos integrados aos estudos territoriais sob a ótica da implantação do Parque Nacional da Chapada das Mesas, sertão de Carolina - MA. Tese de doutorado. Universidade Estadual Paulista, Presidente Prudente.

MARTINS, F.P., SALGADO, A.A.R. \& BARRETO, H.N. 2017. Morfogênese da Chapada das Mesas (Maranhão Tocantins): paisagem cárstica e poligenética. Rev. Bras. Geomorfol. 18(3): 623-635.

MENDONÇA, R.C., FELFILI, J.M., WALTER, B.M.T., SILVA JÚNIOR, M.C., REZENDE, A.V., FILGUEIRAS, T.S., NOGUEIRA, P.E. \& FAGG, C.W. 2008. Flora vascular do cerrado: Chechlist com 12.356 espécies. In Cerrado: ecologia e flora (S.M. Sano, S.P. Almeida \& J.F. Ribeiro, eds). EmbrapaCPAC, Planaltina, p.417-1279.

MICKEL, J.T. \& SMITH, A.R. 2004. The Pteridophytes of Mexico. Memoirs of the New York Botanical Garden 88: 1-1054.

MORAN, R.C \& RIBA, R. 1995. Flora Mesoamericana. Psilotaceae a Salviniaceae. Universidade Nacional Autônoma do México, México, v.1, p.470.

MORAN, R.C., 2008. Diversity, biogeography, and floristics. In Biology and evolution of ferns and lycophytes (T.A. Ranker \& C.H. Haufler, eds). Cambridge University Press, New York, p.367-394.

MORAN, R.C. 2012. A Natural History of Ferns. Timber Press, Portland.

MORAN, R.C. \& SMITH, A.R. 2001. Phytogeographic relationships between and African-Madagascar pteridophytes. Brittonia 53(2): 304-351.

MUSSELMAN, L.J. 2002. Ornamentation of Isoëtes (Isoëtaceae, Lycophyta) microspores. Bot. Rev. 68: 474.

ØLLGAARD, B. 1995A. Lycopodiaceae. In Flora Mesoamericana. Psilotaceae a Salviniaceae (R.C. Moran \& R. Riba, eds). Universidade Nacional Autónoma de México, Ciudad de México, v.1, p.5-22.

ØLLGAARD, B. 1995 B. Lycopodiaceae. In Flora of the Venezuelan Guayana, 2. Pteridophytes, Spermatophytes: Acanthaceae-Araceae (P.E. Berry, B.K. Holst \& K. Yatskievych, eds). Timber Press, Portland, p.190-206.

ØLLGAARD, B. 2012. Nomenclatural changes in Brazilian Lycopodiaceae. Rodriguésia 63: 479-482.

ØLLGAARD, B. \& WINDISCH P.G. 2016. Lycopodiaceae no Brasil. Conspectus da família II. Os gêneros Lycopodiella, Palhinhaea, e Pseudolycopodiella. Rodriguésia 67 (3): 691-719.

PALLOS, J., GÓES-NETO, L.A.A., COSTA J.M., SOUZA, F.S. \& PIETROBOM M.R. 2016. Licófitas e samambaias da Serra do Itauajuri, PA, Brasil. Rodriguésia 67(4): 997-1009.

PAULA-ZÁRATE, E.L. 2005. Florística e fitogeografia das pteridófitas do Estado do Ceará, Brasil. Tese de doutorado, Universidade de São Paulo, São Paulo.

PEREIRA, B.A.S., VENTUROLI, F. \& CARVALHO, F.A. 2011. Florestas Estacionais no Cerrado: Uma Visão Geral. Pesq. Agropec. Trop. 41(3): 446-455. 
PFEIFFER, N.E. 1922. Monografia das Isoëtaceae. Ann. Mo. Bot. Gard. 9(2): 79

PIETROBOM M.R. \& BARROS I.C.L. 2003. Pteridófitas de um fragmento florestal na Serra do Mascarenhas, Estado de Pernambuco, Brasil. Insula 32: $73-118$.

PPG I. The Pteridophyte Phylogeny Group. 2016. A community-derived classification for extant lycophytes and ferns. J. Syst. Evol. 54 (6): 563-603.

PRADO, J. \& SYLVESTRE, L.S. 2010. Introdução: as samambaias e licófitas do Brasil. In Catálogo de plantas e fungos do Brasil (R.C. Forzza, org). Andrea Jakobsson Estúdio: Instituto de Pesquisa Jardim Botânico do Rio de Janeiro, Rio de Janeiro, p.69-74.

PRYER, K.M., SCHNEIDER, H., SMITH, A.R., CRANFILL, R., WOLF, P.G., HUNT, J.S. \& SIPES, S.D. 2001. Horsetails and Ferns are a Monophyletic Group and the Closest Living Relatives to Seed Plants. Nature 409: 618-622.

RBH. https://www.botanica.org.br/catalogo-da-rede-brasileira-de-herbarios/ (último acesso em 27 Set 2019).

ROLLERI, C., \& PRADA, C. 2007. Caracteres diagnósticos foliares en Isoëtes (Pteridophyta, Isoetaceae). Ann. Mo. Bot. Gard. 94(1): 202-235.

SANTIAGO, A.C.P., SOUSA, M.A., SANTANA, E.S. \& BARROS, I.C.L. 2014. Samambaias e licófitas da Mata do Buraquinho, Paraíba, Brasil. Biotemas 27(2): 9-18.

SCHULZ, C., HOMBERG, J. \& STÜTZEL, T. 2013. Taxonomic revision of Selaginella subg. Ericetorum. Syst. Bot. 38: 5-14.

SANTOS-SILVA, D.L., SILVA, G.S., OLIVEIRA, R.R. \& CONCEIÇÃO, G.M. 2018. Nova ocorrência de Lycopodiaceae (lycophyta) para o Estado do Maranhão: Pseudolycopodiella carnosa (Silveira) Holub. Biota Amazônia 8(2): 58-59

SILVA, G.S., SILVA, D.L.S., OLIVEIRA, R.R., SILVA, M.L.A. \& CONCEIÇÃO, G.M. 2017. Licófitas e Samambaias no Cerrado do Leste do Maranhão, Brasil. Acta Bra. 1(2): 13-16.

SILVA, I.A.A. 2014. Composição e riqueza de samambaias e licófitas em florestas serranas do Nordeste do Brasil: influência de fatores físicos e conservação. Tese de doutorado. Universidade Federal de Pernambuco, Recife.

SILVA, A.T., 1989. Pteridófitas. In Técnicas de coleta, preservação e herborização de material botânico (O. Fidalgo \& V.L.R. Bononi, Eds). Instituto de Botânica, São Paulo p. 32-34.

SILVA JUNIOR, C.H.L., ANDERSON, L.O.E.I.N, ARAGÃO, L.E.O.C. \& RODRIGUES, B.D. 2018. Dinâmica das Queimadas no Cerrado do Estado do Maranhão, Nordeste do Brasil. Rev. Dep. Geogr. 35: 1-14.
SILVESTRE, L.C. 2018. Samambaias e Licófitas: florística e aspectos biogeográficos na Floresta Atlântica no Nordeste do Brasil. Tese de doutorado, Universidade Federal do Rio Grande do Norte, Natal.

SILVESTRE L.C., MENDONÇA, J.D.L., XAVIER, S.R.S. \& JADIM, J.G. 2019. Riqueza e similaridade florística de samambaias e licófitas na Floresta Atlântica no Nordeste do Brasil. Oecol. Aust. 23(3): 480-495.

SIMABUKURO, E.A., ESTEVES, L.M. \& FELIPPE, G.M. 1994. Lista de pteridófitas da mata ciliar da Reserva Biológica de Moji Guaçu, SP. Insula 23: 91-98.

SMITH, A.R. 1995. Selaginellaceae. In Flora of the Venezuelan Guayana 2. Pteridophytes, Spermatophytes: Acanthaceae-Araceae (P.E. Berry, B.K Holst \& K. Yatskievych, eds). Timber Press, Portland, p.296-314.

TAYLOR, W. \& HICKEY, R. 1992. Habitat, Evolution, and Speciation in Isoëtes. Ann. Mo. Bot. Gard. 79(3): 613-622.

THIERS, B. 2019. [continuously updated]. Index Herbariorum: A global directory of public herbaria and associated staff. New York Botanical Garden's Virtual Herbarium. http://sweetgum.nybg.org/science/ih/ (último acesso em 05 Agost 2019)

TROIA, A., PEREIRA, J.B.S., KIM, C., TAYLOR, W.C. 2016. The genus Isoetes (Isoetaceae): A provisional checklist of the accepted and unresolved taxa. Phytotaxa 277(2): 101-145. https://doi.org/10.11646/phytotaxa.277.2.1.

TROPICOS. http://www.tropicos.org/Name/26616606 (último acesso em 01 Out 2019)

TRYON, R.M. \& STOLZE, R.G. 1994. 22. Marsileaceae - 28. Isoëtaceae. In Pteridophyta of Peru. Fieldiana Bot. v. 32, Part 6. p.1-190

TRYON, R.M. \& TRYON, A.F. 1982. Ferns and allied plants with special reference to Tropical America. Springer - Verlag, New York, p.857.

WALTER B.M.T. 2006. Fitofisionomias do bioma Cerrado: síntese terminológica e relações florísticas. Tese de doutorado, Universidade de Brasília, Brasília.

WINDISCH, P.G. 1992. Pteridófitas da Região Norte-Ocidental do Estado de São Paulo: guia para excursões. 2 ed. Universidade Estadual Paulista, São José do Rio Preto, p.110. 